

\section{On Ideology and Art Creation: Vienna vs. Hong Kong}

\section{Shui Ki Law}

When it comes to art, we have to study the relationship between artistic production and ideology. Ideology is an abstract word, and it is often hard to grasp what is meant by that. There are various definitions and explanations of what ideology is. For instance, Stuart Hall defines ideology as a framework for thinking and calculating the world, in which people use thought to describe how the social world works, their own position, and what should be done (Makus, 1990). Others cite capitalism, socialism, communism, or even feminism as examples of the most common ideologies. To others, like Louis Althusser, ideology penetrates every corner and through ideological and repressive state apparatuses interpellates people as subjects. Moreover, ideology is in this sense materialized, present in everyday rituals, in our material and aesthetic surroundings, in art. Nobody can escape this ideological interpellation (Althusser, 1971). In the following, I will discuss how differently interpellated are the artists in Vienna on the one hand, and in Hong Kong on the other.

Generally speaking, artists in Austria, Europe, create their artworks with various motivations or just for the sake of creation (Elger, 2004). Nonetheless, ideology shines through their work, even if they would like to perceive themselves as free of it. The artwork by Klaus Peter Scheuringer - ECHO BIRMA, presented at the exhibition Artists' Waste, Wasted Artists, can serve us as an example. According to the interview with Klaus, ECHO BIRMA is a kind of montage art which is a 'bazaar art-history' of his life, 'still coming to the present now'. Since ECHO BIRMA is a collection which includes six series, in each series, there is a valuable myth - 'they are individual mythologies', as he says. This artwork is full of fragments and documents which include his sketches or photographs drawn and printed on used paper or books. The drawings can be drafts or writings, or even abstract graffiti. While photographs can be like traditional frames, printed photos in black in white, to name but a few. It also consists of pieces of newspaper and leaflets; these materials are seen as 'relics' from the artist that tell nonlinear stories and form a sketchy mind map in each series.

When it comes to motivation, Klaus stated that he created those maps in situations without thinking of them as artworks. In other words, he did not intend to create the artworks at the very beginning. Then, how did he end up calling this work ECHO BIRMA? Birma is a synonym of the other side of life, while Echo is expressing the meaning of the far away. Therefore, ECHO BIRMA is a playful fictional term which sounds or feels good to him or otherwise, it provides a touch of exoticism that he prefers. Moreover, to him, ECHO BIRMA is a dadaistic punky phrase, which he relates to the way he works: 'I collect my scraps, notepads and wasted materials for many years because I love those unsophisticated echoic memories.' Nevertheless, he emphasises that those are not diaries but myths without explanation, they have an experimental rather than commercial value. His artwork is not strictly conceptual, yet we may read a number of underlying ideas in it. For example, we will know about Klaus through the work he created, it may only be a rough idea, but we can still estimate his personality and his style - we may be able to say something about his ideological interpellation, 
something he may not necessarily be reflective about himself. It may tell us about what sort of attitude is expected of an artist in the Viennese market, what is valorised - such as the personal, individual, autonomous, reflection and emotion.

Art itself is perceived here as a kind of sacrifice - artists should dedicate themselves fully and selflessly to their art (Abbing, 2002). Artists in Europe treasure their artworks and the creations by other artists like precious stones, to them, these personal manifestations of genius and sacrifice are of high value. However, artists from Hong Kong, a context with which I am more familiar, are very different from the European artists. While they treasure what they create, they are not giving themselves fully to their creations. This lack of full sacrifice to the ideal of art can be one contributing reason to the art market's recession in Hong, as such attitudes also affect the desire or lack thereof, of the buyers (Sun, 2017). Moreover, in this pragmatic Hong Kong society, people are not susceptible to art that is not down-to-earth, to art that may be too idealistic, or high-flying (Abbas, 1997).

The root of this problem regarding local art creation, lies in the promotion of art policy by the government. The government has always placed heavy emphasis on encouraging the public to engage in art, but mostly only as a recreational or everyday activity involved (through the Leisure and Cultural Service Department), which to a large degree obliterates the importance of culture. The idea that 'everyone is an artist' presents several serious problems: 1. The resources allocated for promoting art development are far higher than in the neighboring cities but since everyone thinks they are eligible to enjoy these resources, and since their purpose is not to be an artist, they are not necessarily distributed fairly; resources are always less than demand, hence they cannot satisfy everyone, which means that often 'real artists' cannot survive within the cruel reality, as hobby painters take over. As a result, the quality of local art is not professional enough. 2. Since the quality is not being ensured in this industry, the entry and employment are easy comparatively speaking, which also means that people do not respect and admire the local art due to the low entry threshold. When art is not scarce, or of high quality, no one is going to treasure it; hence the preference has been for a foreign creation or imported art more than the local one. This creates the illusion that foreigner art products are always better compares to the local ones. 3. There are too few measures or policies designed to nurture the real artists who are determined or talented to work in the art industry. Without financial support, they are not eligible to earn their living and lose their ability to develop their artistic path and hence they often move into another industry which is more practical and concrete - at least they can be selfsufficient - this leads to talent loss in this industry. 4. Because the government promoted that everyone can all be an artist, the government is interested in transforming all preartists into so-called 'real' artists, which leads to too many mediocre artists with a limited audience that understands art. This results in Hong Kong having a lot of artistic activities, but serious lack of viewers or admirers (Bob McKercher, 2005).

Even if the local artists are not very dedicated to the local art, and always believe that 'foreign is better', they reluctantly mimic foreign concepts or works and incorporate them into their way of producing artworks. The trend of constructing art in Hong Kong has then become the following: originality is not utmost important in the local art world, instead, to keep up with 'international standards' is the most crucial element. In this 
case, Hong Kong art can never properly develop from one generation to another, each generation of artists learns from those abroad, so there is no unique Hong Kong style. Artwork without specific features and originality cannot consequently attract art buyers and audiences (collectors or the general public), the market is subsequently crushed due to lack of demand, and finally, all artists and creators can only rely entirely on government funding.

Regarding the field of Hong Kong art workers and artists, there is a kind of unique ideology within the artistic trends: Hong Kong public is not dedicated to or respects local artists, this includes both the artists and audience. The previous generation of artists are not recognized by the new generations, subsequently, their creations do not have any impact on the next generation. On the contrary, young artists tend to refuse the local creations by the previous generation, they instead look for foreign countries to imitate, which reflects that the Hong Kong local artists are losing their positions and advantages in the art industry, not to mention their value.

This points to the role of the ideological state apparatuses and the global art market which interpellates the artists. We should not underestimate the power of the social environment (government and market), institutional cultures and so on, also in the case of Vienna - even if there, with the focus on the individual, on experience, on emotion, and devotion to art, ideological forces may be denied. As Louis Althusser mentioned, each artwork is built of aesthetics and conceive of ideology (Althusser, 2001).

Abbing, H. 2002. Why Are Artists Poor? The Exceptional Economy of the Arts. Amsterdam: Amsterdam University Press.

Abbas, A. 1997. Hong Kong: Culture and the Politics of Disappearance. Hong Kong: Univ Of Minnesota Press.

Althusser, L. 2001. Lenin and Philosophy and Other Essays. New York: NY: Monthly Review Press.

Althusser, L. 1971. 'Ideology and Ideological State Apparatuses', In Brewster, T. B. (ed.) Lenin and Philosophy, and Other Essays New Left Books, London, pp. 127-188.

Elger, D. 2004. Dadaism. Köln: Taschen.

Makus, A. 1990. 'Stuart Hall's Theory of Ideology: A Frame for Rhetorical Criticism', Western fournal of Speech Communication, 494-514.

McKercher, B., Ho, P. S. and du Cros, H. 2005. Relationship between tourism and cultural heritage management: evidence from Hong Kong. Hong Kong: Elsevier Ltd. .

Sun, N. 2017. Hong Kong art market takes hit from Beïing's efforts to curb capital outflows. Hong Kong: South China Morning Post. 